\title{
Production of metabolites from Scenedesmus sp. and a microalgal consortium cultured in unconventional media
}

\section{Producción de metabolitos de Scenedesmus sp. y un consorcio microalgal cultivados en medios no convencionales}

\author{
Kevin A González-Falfán, Claudia Guerrero-Barajas, Jesús A Badillo-Corona, \\ Luis C Fernández-Linares* \\ Unidad Profesional Interdisciplinaria de Biotecnología-Instituto Politécnico Nacional, Av. Acueducto s/n, \\ Col. Barrio la Laguna Ticomán, 07340, Mexico City, Mexico \\ * Corresponding author. E-mail: 1fernand36@gmail.com
}

\begin{abstract}
Growth comparisons were made between a microalgal consortium and Scenedesmus sp. cultivated in treated wastewater (TWw) enriched with $1 \mathrm{~mL} \cdot \mathrm{L}^{-1}$ Bayfolan Forte fertilizer $(\mathrm{BM})$, TWw enriched with $\left(\mathrm{NH}_{4}\right)_{2} \mathrm{HPO}_{4}(\mathrm{PAM})$, TWw enriched with $\mathrm{NH}_{4} \mathrm{HCO}{ }_{3}(\mathrm{BCAM})$, tap water with piggery wastewater (PEM), tap water with piggery wastewater digestate (PDM), and raw wastewater (Ww). Nitrogen (N) content in the media, except for TWw, was adjusted to $80 \mathrm{mg} \cdot \mathrm{L}^{-1} \mathrm{~N}\left(\mathrm{NH}_{4}{ }^{+}-\mathrm{N}\right.$ and $\left.\mathrm{NO}_{3}{ }^{-} \mathrm{N}\right)$. Unconventional low-cost media with lower nutrient contents (BM and TWw) showed adequate productions of biomass and lipids. PEM was the most advantageous medium, showing the highest biomass productivity with the consortium $\left(191.25 \pm 6.25 \mathrm{~g} \cdot \mathrm{L}^{-1} \cdot \mathrm{d}^{-1}\right)$ and a lipid productivity of $36.75 \pm 9.90 \mathrm{mg} \cdot \mathrm{L}^{-1} \cdot \mathrm{d}^{-1}$. The fatty acid profile was composed mainly of C16 and C18. PAM, PEM, and PDM showed a higher proportion of saturated fatty acids $(60 \%-69 \%)$, whereas the composition of unsaturated fatty acids was in the range of $31 \%$ to $38 \%$. In PEM and PDM the removal of $\mathrm{NH}_{4}^{+}$was $100 \%$; however, there were $\mathrm{NH}_{4}^{+}$losses (as $\mathrm{NH}_{3}$ ) due to volatilization (46\%). Unconventional media, especially $\mathrm{Ww}$, are an option for growing microalgae.
\end{abstract}

Key words: fertilizer, microalgae-bacteria consortium, Scenedesmus sp., wastewater.

RESUMEN. Se comparó el crecimiento de un consorcio de microalgas y de Scenedesmus sp. cultivados en aguas residuales tratadas (ART) enriquecidas con $1 \mathrm{~mL} \cdot \mathrm{L}^{-1}$ de fertilizante Bayfolan Forte $(\mathrm{MB})$, ART enriquecidas con $\left(\mathrm{NH}_{4}\right)_{2} \mathrm{HPO}_{4}(\mathrm{MPA}), \mathrm{ART}$ enriquecidas con $\mathrm{NH}_{4} \mathrm{HCO}{ }_{3}$ (MBCA), agua del grifo con aguas residuales porcinas (MEP), agua del grifo con digestato de aguas residuales porcinas (MDP) y aguas residuales sin tratar (AR). El contenido de nitrógeno (N) de los medios, excepto el medio AR, se ajustó a $80 \mathrm{mg} \cdot \mathrm{L}^{-1}$ de $\mathrm{N}\left(\mathrm{NH}_{4}^{+}-\mathrm{N}\right.$ y $\left.\mathrm{NO}_{3}^{-}-\mathrm{N}\right)$. Los medios no convencionales con menor contenido de nutrientes y costo (MB y AR) presentaron buenas producciones de biomas y lípidos. MEP fue el medio más ventajoso al presentar la mayor productividad de biomasa con el consorcio $\left(191.25 \pm 6.25 \mathrm{~g} \cdot \mathrm{L}^{-1} \cdot \mathrm{d}^{-1}\right) \mathrm{y} u n a$ productividad de lípidos de $36.75 \pm 9.90 \mathrm{mg} \cdot \mathrm{L}^{-1} \cdot \mathrm{d}^{-1}$. El perfil de ácidos grasos estuvo constituido principalmente de C16 y C18. MPA, MEP y MDP mostraron una mayor proporción de ácidos grasos saturados (60\%-69\%), mientras que la composición de los ácidos grasos insaturados osciló entre $31 \%$ y $38 \%$. En MEP y MDP, la eliminación de $\mathrm{NH}_{4}{ }^{+}$fue del 100\%; sin embargo, hubo pérdidas de $\mathrm{NH}_{4}{ }^{+}$debido al arrastre por aire (46\%). Los medios no convencionales, específicamente las AR, son una opción para el cultivo de microalgas.

Palabras clave: fertilizante, consorcio de microalgas-bacterias, Scenedesmus sp., aguas residuales.

\section{INTRODUCTION}

The production of biofuels from microalgae is promising because microalgae do not compete for food crops or arable land, present high growth rates, and are capable of fixing $\mathrm{CO}_{2}$ through photosynthesis and releasing $\mathrm{O}_{2}$ into the atmosphere. Nitrogen $(\mathrm{N})$ is a key nutrient for the growth and biochemical composition of microalgae, and the accumulation of lipids and carbohydrates increases under $\mathrm{N}$ limitation (Liu et al. 2017, Huy et al. 2018).

One of the main problems of large-scale microalgal biomass production is the supply of $\mathrm{N}$ and phosphorous $(\mathrm{P})$. $\mathrm{N}$ fertilizers require enormous amounts of fossil energy (Metz et al. 2007), the main contributor to the carbon footprint (Hillier et al. 2009). Moreover, the use of fertilizers for culturing microalgae competes

\section{INTRODUCCIÓN}

La producción de biocombustibles a partir de microalgas es prometedora, debido a que las microalgas no compiten por cultivos alimenticios ni por tierras arables, presentan altas tasas de crecimiento y son capaces de fijar $\mathrm{CO}_{2}$ mediante fotosíntesis y liberar $\mathrm{O}_{2}$ a la atmósfera. El nitrógeno $(\mathrm{N})$ es un nutriente clave para el crecimiento y la composición bioquímica de las microalgas, y la acumulación de lípidos y carbohidratos aumenta en condiciones de limitación de N (Liu et al. 2017, Huy et al. 2018).

Uno de los principales problemas en la producción a gran escala de biomasa microalgal es el suministro de $\mathrm{N}$ y fósforo (P). Los fertilizantes de $\mathrm{N}$ requieren de una enorme cantidad de energía fósil (Metz et al. 2007), el principal contribuyente a la huella de carbono (Hillier et al. 2009). 
with their use in agriculture (Chisti 2013). One of the obstacles to large-scale production of microalgae for energy purposes is still the high cost of production, especially the availability and cost of feedstock (Acién et al. 2012).

The use of organic fertilizers such as animal excreta, sludge from wastewater, and anaerobic digestate with high nutrient contents has been proposed as an economical alternative for microalgae culture (Nayak et al. 2016, Wang et al. 2016a, El Shimi and Moustafa 2017, Liu et al. 2017, Huy et al. 2018). The use of wastewater (Gonçalves et al. 2017, Ho et al. 2019, Rodríguez-Mata et al. 2019) and wastewater enriched with inorganic fertilizers, composed of $\mathrm{N}, \mathrm{P}$, and potassium $(\mathrm{K})$, is an economical alternative for large-scale cultivation (Nayak et al. 2016).

Microalgae can remove $\mathrm{N}$ and $\mathrm{P}$ from municipal wastewater, leaving very low concentrations, while converting these nutrients into biomass (Boelee et al. 2011). The microalgae genera Chlorella and Scenedesmus are the most studied in regards to their culture in wastewaters, particularly the species Chlorella vulgaris and Scenedesmus obliquus (Park et al. 2010, Ji et al. 2013, Xu et al. 2015, Wang et al. 2016b). Scenedesmus obliquus has been used to treat wastewater and to obtain valuable biomass in bubble-column photobioreactors. Scenedesmus obliquus grown in a culture medium supplemented with $40 \%$ of piggery wastewater effluent showed biomass and lipid productivities of 15.5 and 0.13 $\mathrm{mg} \cdot \mathrm{L}^{-1} \cdot \mathrm{d}^{-1}$, respectively, and removals of $96.1 \mathrm{mg}$ total $\mathrm{N}$ and $2.48 \mathrm{mg}$ total $\mathrm{P}$ were observed ( $\mathrm{Ji}$ et al. 2013). Removal of $79 \%$ of $\mathrm{NH}_{4}{ }^{+}$and $43 \%$ of $\mathrm{PO}_{4}{ }^{3-}$ from a mixture of wastewater (containing $145.2 \mathrm{mg} \cdot \mathrm{L}^{-1} \mathrm{NH}_{4}{ }^{+}$and $21.1 \mathrm{mg} \cdot \mathrm{L}^{-1} \mathrm{PO}_{4}{ }^{3-}$ ) and $7 \%$ of landfill leachate was achieved with $S$. obliquus, which accumulated $12 \%-16 \%$ of lipids in cells (Hernández-García et al. 2019). When Scenedesmus sp. AMDD was grown in treated municipal wastewater in chemostats under different dilution rates or hydraulic retention times, biomass composition was strongly controlled by the rate of wastewater nutrient removal, and total fatty acids were only accumulated when growth rates were very low or when a prolonged nutrient starvation regime was imposed (Dickinson et al. 2013). Microalgae production using secondary treated wastewater decreases process costs by minimizing the use of freshwater and fertilizers while contributing to the water purification process, greatly enhancing process sustainability (Gómez et al. 2013).

The present work compares the effect of 6 unconventional media (3 inorganic and 3 organic), some of which were used and compared for the first time, on the growth and productivity of a microalgal consortium and Scenedesmus sp. and proposes different media for scaling microalgae culture in a sustainable way.
Asimismo, el uso de fertilizantes para el cultivo de microalgas compite con su utilización en la agricultura (Chisti 2013). Uno de los obstáculos para la producción de microalgas a gran escala con fines energéticos sigue siendo el alto costo de producción, especialmente la disponibilidad y el costo de la materia prima (Acién et al. 2012).

Se ha propuesto la utilización de fertilizantes orgánicos como excretas animales, lodos de aguas residuales y digestatos anaerobios con alto contenido de nutrientes como una alternativa económica para el cultivo de microalgas (Nayak et al. 2016, Wang et al. 2016a, El Shimi y Moustafa 2017, Liu et al. 2017, Huy et al. 2018). La utilización de aguas residuales (Gonçalves et al. 2017, Ho et al. 2019, Rodríguez-Mata et al. 2019) y aguas residuales enriquecidas con fertilizantes inorgánicos, compuestos por N, P y potasio $(\mathrm{K})$, es una alternativa económica para el cultivo a gran escala (Nayak et al. 2016).

Las microalgas pueden remover $\mathrm{N}$ y $\mathrm{P}$ de las aguas residuales municipales hasta dejar concentraciones muy bajas, al tiempo que convierten estos nutrientes en biomasa (Boelee et al. 2011). Los géneros de microalgas Chlorella y Scenedesmus son los más estudiados en cuanto a su cultivo en aguas residuales, particularmente las especies Chlorella vulgaris y Scenedesmus obliquus (Park et al. 2010, Ji et al. 2013, Xu et al. 2015, Wang et al. 2016b). Scenedesmus obliquus se ha utilizado para el tratamiento de aguas residuales y la obtención de biomasa en fotobiorreactores de columna de burbujeo. El cultivo de esta especie en un medio suplementado con $40 \%$ de efluente de aguas residuales de porqueriza mostró productividad de biomasa y lípidos de 15.5 y $0.13 \mathrm{mg} \cdot \mathrm{L}^{-1} \cdot \mathrm{d}^{-1}$, respectivamente, y se observó una remoción de $96.1 \mathrm{mg}$ de $\mathrm{N}$ total y $2.48 \mathrm{mg}$ de $\mathrm{P}$ total (Ji et al. 2013). La remoción del $79 \%$ de $\mathrm{NH}_{4}{ }^{+}$y $43 \%$ de $\mathrm{PO}_{4}{ }^{3-}$ de una mezcla de aguas residuales (contenido de $145.2 \mathrm{mg} \cdot \mathrm{L}^{-1}$ de $\mathrm{NH}_{4}{ }^{+}$y $21.1 \mathrm{mg} \cdot \mathrm{L}^{-1} \mathrm{de} \mathrm{PO}_{4}{ }^{3-}$ ) y $7 \%$ de lixiviado de relleno se logró con $S$. obliquus, que acumuló del $12 \%$ al 16\% de lípidos en las células (Hernández-García et al. 2019). Al cultivar Scenedesmus sp. AMDD en aguas residuales municipales tratadas en quimiostatos con diferentes tasas de dilución o tiempos de retención hidráulica, la composición de la biomasa estuvo fuertemente relacionada con la tasa de eliminación de los nutrientes de las aguas residuales, y los ácidos grasos totales solo se acumularon cuando las tasas de crecimiento fueron muy bajas o cuando se impuso un régimen prolongado de privación de nutrientes (Dickinson et al. 2013). La producción de microalgas utilizando aguas residuales con tratamiento secundario permite disminuir los costos del proceso, al minimizar la utilización de agua dulce y fertilizantes, y contribuye al proceso de purificación del agua, lo que mejora, en gran medida, la sostenibilidad del proceso (Gómez et al. 2013).

El presente trabajo compara el efecto de 6 medios no convencionales (3 inorgánicos y 3 orgánicos), algunos de ellos utilizados y comparados por primera vez, sobre el 


\section{MATERIALS AND METHODS}

\section{Pretreatment and characterization of treated water, wastewater, and piggery wastewater}

The wastewater (Ww) and the secondary treated wastewater (TWw) were obtained from the "San Juan Ixhuatepec" treatment plant located in Tlalnepantla, Mexico $\left(19^{\circ} 31^{\prime} 13.8^{\prime \prime} \mathrm{N}, 9^{\circ} 07^{\prime} 27.8^{\prime \prime} \mathrm{W}\right)$. Ww and TWw were not filtered or sterilized. Piggery wastewater and piggery wastewater digestate were obtained from Productora Porcina Nopaltepec, located in Nopaltepec, Mexico $\left(19^{\circ} 47^{\prime} 03.5^{\prime \prime} \mathrm{N}\right.$, $\left.98^{\circ} 43^{\prime} 41.6^{\prime \prime} \mathrm{W}\right)$. Both piggery wastewater and piggery wastewater digestate were centrifuged at $6,000 \mathrm{rpm}$ for $5 \mathrm{~min}$ to remove the solids, and the supernatant was used as substrate. The compositions of the TWw, piggery wastewater, piggery wastewater digestate, and Bayfolan fertilizer used to prepare the culture media are described in Table 1.

\section{Culture media}

The 6 proposed media used in this work for culturing were (1) Bayfolan medium (BM), formulated with $1 \mathrm{~mL}$ of Bayfolan Forte per liter of TWw; (2) TWw enriched with $0.3303 \mathrm{~g} \cdot \mathrm{L}^{-1}\left(\mathrm{NH}_{4}\right)_{2} \mathrm{HPO}_{4}(\mathrm{PAM})$; (3) TWw supplemented with $0.1977 \mathrm{~g} \cdot \mathrm{L}^{-1} \mathrm{NH}_{4} \mathrm{HCO}_{3}$ (BCAM); (4) tap water with $23.5 \%$ of piggery wastewater (PEM); (5) tap water with $39.75 \%$ of piggery wastewater digestate (PDM); and (6) Ww. N content in BM, PAM, and BCAM was adjusted to $80 \mathrm{mg} \cdot \mathrm{L}^{-1} \mathrm{~N}\left(\mathrm{NH}_{4}{ }^{+}-\mathrm{N}\right.$ and $\left.\mathrm{NO}_{3}{ }^{-} \mathrm{N}\right)$, according to conventional media $\mathrm{BBM}$ and $\mathrm{BG} 11$ with $500 \mathrm{mg} \cdot \mathrm{L}^{-1}$ of sodium nitrate. $\mathrm{N}$ sources for BCAM and PAM were chosen based on their availability on the market, and $\mathrm{NH}_{4} \mathrm{HCO}_{3}$ and $\left(\mathrm{NH}_{4}\right)_{2} \mathrm{HPO}_{4}$ served as sources of carbon $(\mathrm{C})$ and $\mathrm{P}$, respectively. For PEM and PDM, tap water treated in a purification plant was used instead of Ww or TWw because when scaling crecimiento y la productividad de un consorcio de microalgas y Scenedesmus sp., y propone diferentes medios para escalar el cultivo de microalgas de forma sostenible.

\section{Materiales Y MÉTOdos}

Pretratamiento y caracterización de aguas tratadas, aguas residuales $\mathbf{y}$ aguas residuales porcinas

Las aguas residuales sin tratar (AR) y las aguas residuales tratadas secundarias (ART) se obtuvieron de la planta de tratamiento San Juan Ixhuatepec ubicada en Tlalnepantla, México (19³1'13.8' N, 9907'27.8' W). Las AR y las ART no se filtraron ni esterilizaron. Las aguas residuales porcinas y los digestatos de aguas residuales porcinas se obtuvieron de la Productora Porcina Nopaltepec, ubicada en Nopaltepec, México (19 47'03.5' N, 98 43'41.6" W). Tanto las aguas residuales porcinas como los digestatos de aguas residuales porcinas se centrifugaron a $6,000 \mathrm{rpm} / 5 \mathrm{~min}$ para eliminar los sólidos, y se utilizó el sobrenadante como sustrato. Las composiciones de ART, aguas residuales porcinas, digestato de aguas residuales porcinas y Bayfolan empleadas para la preparación de los medios de cultivo se describen en la Tabla 1.

\section{Medios de cultivo}

Los 6 medios propuestos en este trabajo y utilizados para los cultivos fueron (1) medio Bayfolan (MB), formulado con $1 \mathrm{~mL}$ de Bayfolan Forte por litro de ART; (2) ART enriquecidas con $0.3303 \mathrm{~g} \cdot \mathrm{L}^{-1}$ de $\left(\mathrm{NH}_{4}\right)_{2} \mathrm{HPO}_{4}$ (MPA); (3) ART suplementadas con $0.1977 \mathrm{~g} \cdot \mathrm{L}^{-1}$ de $\mathrm{NH}_{4} \mathrm{HCO}_{3}$ (MBCA); (4) agua del grifo con $23.5 \%$ de aguas residuales porcinas (MEP); (5) agua del grifo con $39.75 \%$ de digestatos de aguas residuales porcinas (MDP); y (6) AR. El contenido de $\mathrm{N}$ en MB, MPA y MBCA

Table 1. Composition of the wastewater, treated wastewater, piggery wastewater, and Bayfolan fertilizer used for culture media formulation. Data are presented as mean values and standard errors.

Tabla 1. Composición de las aguas residuales, las aguas residuales tratadas, las aguas residuales porcinas y el medio Bayfolan utilizados para la formulación de los medios de cultivo. Los datos se presentan como la media y el error estándar.

\begin{tabular}{|c|c|c|c|c|c|}
\hline $\mathrm{N}-\mathrm{NH}_{4}^{+}$ & $3.10 \pm 0.14$ & $37.53 \pm 0.18$ & $2,605.80 \pm 67.26$ & $1,540.82 \pm 43.49$ & $44.75 \pm 0.30$ \\
\hline $\mathrm{PO}_{4}{ }^{3-}$ & $15.81 \pm 0.05$ & $15.45 \pm 0.18$ & $851.28 \pm 0.61$ & $259.30 \pm 5.22$ & $10.60 \pm 0.17$ \\
\hline COD & $17.00 \pm 4.15$ & $239.00 \pm 5.50$ & $16,877.30 \pm 397.61$ & $2,368.67 \pm 186.23$ & $92.36 \pm 1.67$ \\
\hline $\mathrm{pH}$ & 7.80 & 8.42 & 7.13 & 8.22 & 7.01 \\
\hline
\end{tabular}

TWw, treated wastewater; Ww, raw wastewater; PEM, tap water with $23.5 \%$ of piggery wastewater; PDM, tap water with $39.75 \%$ of piggery wastewater digestate; BM, Bayfolan medium formulated with $1 \mathrm{~mL}$ of Bayfolan Forte per liter of TWw; COD, chemical oxygen demand; TSS, total suspended solids. 
to $2,000 \mathrm{~L}$ or higher, water transportation from the closest treatment plant implied logistic issues and higher operational costs. Piggery wastewater and the piggery wastewater digestate were selected because of their high $\mathrm{NH}_{4}{ }^{+}$content (Hu et al. 2013, Luo et al. 2016) and low cost.

\section{Microorganisms and pre-culture conditions}

The microalgae Scenedesmus sp. was obtained from the microalgae collection of the Center for Scientific Research and Higher Education at Ensenada, Baja California, Mexico. The microalgal consortium was obtained from treated water and was mainly composed of Scenedesmus sp. and Chlorella sp. The consortium was obtained by growing the native microflora of the treated water from the plant in a 1-L photobioreactor under the conditions described below. The culture was maintained and reinoculated in treated water. Cultures were carried out in 1-L cylindrical photobioreactors (101 $\mathrm{mm}$ diameter $\times 203 \mathrm{~mm}$ height), with working volume of $0.9 \mathrm{~L}$, illuminated on one side by cold-cathode fluorescent lamps $\left(127 \mu \mathrm{E} \cdot \mathrm{m}^{-2} \cdot \mathrm{s}^{-1}\right)$ under a 12:12 (light:dark) photoperiod, with aeration of $0.4 \mathrm{vvm}$ and a temperature of $24 \pm$ $1{ }^{\circ} \mathrm{C}$. Water losses due to evaporation were amended daily by adding sterile distilled water.

Prior to the experimentation, the consortium and Scenedesmus sp. were cultured in the 6 media. To synchronize the pre-cultures, 3 consecutive cultures were carried out during $13 \mathrm{~d}$ each, and the last one was used as the inoculum of the experiments. All the pre-inocula were adjusted to an oxygen demand of $0.8(600 \mathrm{~nm})$ and all the photobioreactors were inoculated at $10 \%$, with the corresponding pre-inoculum.

\section{Culture conditions}

Microalgae were cultivated for $13 \mathrm{~d}$ in BM, PAM, BCAM, and Ww. In PEM and PDM media, microalgae were cultivated during $8 \mathrm{~d}$ because they grew faster in these media. $\mathrm{NH}_{4}^{+}, \mathrm{PO}_{4}{ }^{3-}$, and $\mathrm{NO}_{3}{ }^{-}$contents in the supernatant and productions of biomass, carbohydrates, and proteins were determined every $3 \mathrm{~d}$; pigments, lipids, and the lipid profile were determined at the end of the culture. In addition, the chemical oxygen demand (COD) was determined at the beginning and at the end of the PEM and PDM cultures. $\mathrm{NH}_{4}{ }^{+}$losses by volatilization (as $\mathrm{NH}_{3}$ ) in PEM and $\mathrm{PDM}$ were quantified by passing the outlet of the gas stream from the photobioreactors through a $0.5 \mathrm{M} \mathrm{H}_{2} \mathrm{SO}_{4}$ solution, and dissolved $\mathrm{NH}_{3}$ was determined by a colorimetric method (APHA 1998).

\section{Analytical methods}

Determination of biomass, metabolites, and media composition

Biomass was determined by measuring absorbance at 750 and $600 \mathrm{~nm}$ with a spectrophotometer (DR3000 UV/ Vis Spectrophotometer, HACH; USA). Biomass (dry weight se ajustó a $80 \mathrm{mg} \cdot \mathrm{L}^{-1}$ de $\mathrm{N}\left(\mathrm{NH}_{4}{ }^{+}-\mathrm{N}\right.$ y $\left.\mathrm{NO}_{3}^{-}-\mathrm{N}\right)$, según medios convencionales BBM y BG 11 con $500 \mathrm{mg} \cdot \mathrm{L}^{-1}$ de nitrato de sodio. Las fuentes de N para MBCA y MPA se eligieron en función de su disponibilidad en el mercado, y $\mathrm{NH}_{4} \mathrm{HCO}_{3}$ y $\left(\mathrm{NH}_{4}\right)_{2} \mathrm{HPO}_{4}$ sirvieron como fuentes de carbono (C) y P, respectivamente. Para los medios MEP y MDP, se usó agua del grifo tratada en una planta de purificación en lugar de AR o ART porque cuando se escalan a 2,000 L o más, el transporte de agua desde la planta de tratamiento más cercana implica problemas logísticos y mayores costos operativos. Las aguas residuales y el digestato de aguas residuales porcinas fueron seleccionados por su alto contenido de $\mathrm{NH}_{4}{ }^{+}$(Hu et al. 2013, Luo et al. 2016) y bajo costo.

\section{Microorganismos y condiciones de precultivo}

La microalga Scenedesmus sp. se obtuvo de la colección de microalgas del Centro de Investigación Científica y de Educación Superior de Ensenada, Baja California, México. El consorcio de microalgas se obtuvo a partir de agua tratada, y estuvo compuesto, principalmente, por Scenedesmus sp. y Chlorella sp. Este consorcio se obtuvo cultivando la microflora nativa del agua tratada de la planta en un fotobiorreactor de $1 \mathrm{~L}$ en las condiciones que se describen a continuación. El cultivo se mantuvo y reinoculó en agua tratada. Los cultivos se realizaron en fotobiorreactores cilíndricos de $1 \mathrm{~L}(101 \mathrm{~mm}$ de diámetro $\times 203 \mathrm{~mm}$ de altura), con volumen de trabajo de $0.9 \mathrm{~L}$, iluminados de un lado por lámparas fluorescentes de luz fría $\left(127 \mu \mathrm{E} \cdot \mathrm{m}^{-2} \cdot \mathrm{s}^{-1}\right)$ en fotoperiodo de 12:12 (luz:oscuridad), con aireación de $0.4 \mathrm{vvm}$ y una temperatura de $24 \pm 1{ }^{\circ} \mathrm{C}$. Las pérdidas de agua por evaporación se restituyeron diariamente adicionando agua destilada estéril.

Antes de la experimentación, el consorcio y Scenedesmus sp. se cultivaron en los 6 medios. Para sincronizar los precultivos, se realizaron 3 cultivos consecutivos durante $13 \mathrm{~d}$ cada uno, y el último se utilizó como inóculo de los experimentos. Todos los preinóculos se ajustaron a una densidad óptica de $0.8(600 \mathrm{~nm})$, y todos los fotobiorreactores se inocularon al 10\%, con el preinóculo correspondiente.

\section{Condiciones de cultivo}

Las microalgas se cultivaron durante $13 \mathrm{~d}$ en MB, MPA, MBCA y AR. En MEP y MDP se cultivaron durante $8 \mathrm{~d}$ debido a que crecieron más rápido en estos medios. Cada $3 \mathrm{~d}$ se determinó el contenido de $\mathrm{NH}_{4}{ }^{+}, \mathrm{PO}_{4}{ }^{3-}$ y $\mathrm{NO}_{3}{ }^{-}$en el sobrenadante y la producción de biomasa, carbohidratos y proteínas; los pigmentos, los lípidos y el perfil lipídico se determinaron al final del cultivo. Adicionalmente, se determinó la demanda química de oxígeno (DQO) al inicio y al final de los cultivos en MEP y MDP. Las pérdidas de $\mathrm{NH}_{4}{ }^{+}$por volatilización (como $\mathrm{NH}_{3}$ ) en MEP y MDP se 
basis) was determined in a moisture analyzer thermobalance using a glass microfiber membrane (Ahlstrom, $4.7 \mathrm{~cm}$ diameter, $1.1 \mu \mathrm{m}$ pore size). Cells were counted using a Neubauer cell chamber. Protein contents were determined following the Lowry method (Lowry et al. 1951); carbohydrates, by the Dubois method (DuBois et al. 1956); and pigments, by the Wellburn method (Ritchie 2006). $\mathrm{NH}_{4}{ }^{+}, \mathrm{PO}_{4}{ }^{3-}$, and $\mathrm{COD}$ were determined following APHA methods (1998) in APHA (1998), and total suspended solids were measured according to standard methods (APHA 2005). $\mathrm{NO}_{3}^{-}$was analyzed according to the modified method reported by Keeney and Nelson (1982).

\section{Determination of lipids and fatty acid methyl esters}

Lipid extraction was performed as described by RamírezLópez et al. (2016). The composition of fatty acid methyl esters (FAMEs) was determined in an Agilent gas chromatograph (Technologies 7890B; Santa Clara, CA, USA) coupled to mass spectrometry (Agilent Technologies 5977A Series GC/MSD System; Santa Clara, CA, USA). A VF-MAXms column $(30 \mathrm{~m} \times 0.25 \mathrm{~mm}, 0.50 \mu \mathrm{m})$ was used and Helium was the carrier gas at a flow rate of $2.4 \mathrm{~mL} \cdot \mathrm{min}^{-1}$. Injector temperature was maintained at $230^{\circ} \mathrm{C}$. Oven temperature was adjusted to $140{ }^{\circ} \mathrm{C}$ for $5 \mathrm{~min}$ and gradually increased $8{ }^{\circ} \mathrm{C}$ every minute to $250^{\circ} \mathrm{C}$ for $15 \mathrm{~min}$. The temperature of the transfer line (MSD) was maintained at $180^{\circ} \mathrm{C}$. The temperatures of the source and the quadrupole were 230 and $150^{\circ} \mathrm{C}$, respectively. Each peak of FAME was identified and quantified with the standard Supelco 37 Component FAME Mix.

\section{Data analysis}

Factor analysis (analysis of variance, $P \leq 0.05$ ) and the Tukey HDS test were used to compare differences between treatment mean values. All the experiments were performed in triplicate.

\section{Results}

\section{Effect of the medium on the production and productivity of biomass}

The culture medium that yielded the highest biomass concentration (dry weight) of the microalgal consortium and Scenedesmus sp. was BM with $1.79 \pm 0.05$ and $1.77 \pm$ $0.10 \mathrm{~g} \cdot \mathrm{L}^{-1}$, respectively. These concentrations were significantly higher than those obtained in the other 5 culture media. The media that yielded the highest biomass concentrations after $\mathrm{BM}$ were $\mathrm{Ww}$ and PEM, and there was a significant difference in biomass concentrations with respect to BCAM, PAM, and PDM (Fig. 1). Therefore, given the significant differences in biomass production and the increasing trend in biomass productivity, the media can be grouped as follows: $\mathrm{BM}>(\mathrm{Ww}$ and $\mathrm{PEM})>(\mathrm{BCAM}, \mathrm{PAM}$, cuantificaron pasando la corriente de gas de la salida de los fotobiorreactores a través de una solución $0.5 \mathrm{M}$ de $\mathrm{H}_{2} \mathrm{SO}_{4}$, y el $\mathrm{NH}_{3}$ disuelto se determinó por el método colorimétrico (APHA 1998).

\section{Métodos analíticos}

Determinación de biomasa, metabolitos y composición de los medios

La biomasa se determinó por absorbancia a 750 y $600 \mathrm{~nm}$ con un espectrofotómetro (DR3000 UV/Vis, $\mathrm{HACH}$; EUA). La biomasa (con base en el peso seco) se determinó en una termobalanza analizadora de humedad utilizando una membrana de microfibras de vidrio (Ahlstrom, $4.7 \mathrm{~cm}$ de diámetro, $1.1 \mu \mathrm{m}$ de tamaño de poro). El recuento de células se realizó utilizando una cámara de Neubauer. El contenido de proteínas se determinó siguiendo el método de Lowry (Lowry et al. 1951); el de carbohidratos, mediante el método de Dubois (DuBois et al. 1956); y el de los pigmentos, mediante el método de Wellburn (Ritchie 2006). El $\mathrm{NH}_{4}{ }^{+}, \mathrm{PO}_{4}{ }^{3-}$ y DQO se determinaron siguiendo los métodos de APHA (1998), y los sólidos suspendidos totales se midieron de acuerdo con los métodos estándar (APHA 2005). El $\mathrm{NO}_{3}{ }^{-}$se analizó de acuerdo con el método modificado reportado por Keeney y Nelson (1982).

\section{Determinación de lípidos y ésteres metílicos de ácidos grasos}

La extracción de lípidos se realizó según lo descrito por Ramírez-López et al. (2016). La composición de los ésteres metílicos de ácidos grasos (EMAG) se determinó en un cromatógrafo de gases Agilent (Technologies 7890B; Santa Clara, CA, EUA) acoplado a espectrometría de masas (Sistema GC/MSD Agilent Technologies 5977A Series; Santa Clara, CA, EUA). Se utilizó una columna VF-MAXms $(30 \mathrm{~m} \times 0.25 \mathrm{~mm}, 0.50 \mu \mathrm{m})$ y el gas portador fue el helio a una velocidad de flujo de $2.4 \mathrm{~mL} \cdot \mathrm{min}^{-1}$. La temperatura del inyector se mantuvo en $230^{\circ} \mathrm{C}$. La temperatura del horno se ajustó a $140^{\circ} \mathrm{C}$ durante 5 min y se incrementó gradualmente $8{ }^{\circ} \mathrm{C}$ cada minuto hasta $250{ }^{\circ} \mathrm{C}$ durante $15 \mathrm{~min}$. La temperatura de la línea de transferencia (MSD) se mantuvo a $180{ }^{\circ} \mathrm{C}$. Las temperaturas de la fuente y del cuadrupolo fueron de 230 y $150{ }^{\circ} \mathrm{C}$, respectivamente. Cada pico de EMAG se identificó y cuantificó con la mezcla estándar de EMAG de 37 componentes de Supelco.

\section{Análisis de los datos}

Se utilizó el análisis factorial (análisis de varianza, $P \leq$ $0.05)$ y la prueba de Tukey HDS para comparar las diferencias entre las medias de los tratamientos. Todos los experimentos se realizaron por triplicado. 
and PDM), BM being the medium that yielded the highest biomass productivity.

\section{Effect of the medium on lipid productivity and fatty acid methyl esters}

The content of lipids in biomass in both the consortium and Scenedesmus sp. was $15 \%-16 \%$ in BCAM, 16\%-22\% in PAM, $9 \%-13 \%$ in $\mathrm{BM}, 21 \%-23 \%$ in $\mathrm{Ww}, 19 \%-32 \%$ PEM, and $30 \%-52 \%$ in PDM (Fig. 2). Lipid productivity in both cases, the consortium and Scenedesmus sp., fluctuated between 34.25 and $36.75 \mathrm{mg} \cdot \mathrm{L}^{-1} \cdot \mathrm{d}^{-1}$ in PEM, 32.83 and $38.67 \mathrm{mg} \cdot \mathrm{L}^{-1} \cdot \mathrm{d}^{-1}$ in PDM, and 24.87 and $26.41 \mathrm{mg} \cdot \mathrm{L}^{-1} \cdot \mathrm{d}^{-1}$ in $\mathrm{Ww}$, all significantly higher than the lipid productivities obtained in BM, BCAM, and PAM (Table 2). In Ww, BCAM, PAM, PEM, and PDM, $90 \%-100 \%$ of $\mathrm{NH}_{4}^{+}$was removed from day 3 and, consequently, there was $\mathrm{N}$ limitation.

The fatty acid profiles for the microalgal consortium and Scenedesmus sp. in the different media consisted of palmitic acid (C16:0), palmitoleic acid (C16:1), stearic acid (C18:0), oleic acid (C18:1), linoleic acid (C18:2), and linolenic acid (C18:3) (Table 3), which are suitable for the production of biodiesel (Anand et al. 2018, May-Cua 2019). The culture media PAM, PEM, and PDM exhibited a higher proportion of saturated fatty acids $(60 \%-69 \%$ of total FAMEs) than BCAM, BM, and $\mathrm{Ww}(39 \%-48 \%$ of total FAMEs).

Effect of the medium on the productivity of proteins, carbohydrates, and total pigments

The productivities of proteins in the microalgal consortium and Scenedesmus sp. cultures with BM and PEM

\section{RESUltados}

\section{Efecto del medio de cultivo en la producción y la productividad de biomasa}

El medio de cultivo con la mayor concentración de biomasa (peso seco) del consorcio de microalgas y Scenedesmus sp. fue $\mathrm{MB}$ con $1.79 \pm 0.05$ y $1.77 \pm 0.10 \mathrm{~g} \cdot \mathrm{L}^{-1}$, respectivamente. Estas concentraciones fueron significativamente superiores a las obtenidas en los otros 5 medios de cultivo. Los medios que dieron la mayor concentración de biomasa después de MB fueron AR y MEP, con una diferencia significativa en la concentración de biomasa respecto a MBCA, MPA y MDP (Fig. 1). Por tanto, dadas las diferencias significativas en la producción de biomasa y la tendencia del aumento de la productividad de la biomasa, los medios se pueden agrupar de la siguiente forma: MB > (AR y MEP) > (MBCA, MPA y $\mathrm{MDP}$ ), con $\mathrm{MB}$ como el medio que produjo la mayor productividad de biomasa.

\section{Efecto del medio sobre la productividad lipídica y los ésteres metílicos de ácidos grasos}

El contenido de lípidos en la biomasa tanto en el consorcio como en Scenedesmus sp. fue del 15\%-16\% en MBCA, $16 \%-22 \%$ en MPA, $9 \%-13 \%$ en MB, $21 \%-23 \%$ en AR, $19 \%-32 \%$ en MEP y $30 \%-52 \%$ en MDP (Fig. 2). La productividad de los lípidos en ambos casos, el consorcio y Scenedesmus sp., fluctuó entre 34.25 y $36.75 \mathrm{mg} \cdot \mathrm{L}^{-1} \cdot \mathrm{d}^{-1}$ en MEP, 32.83 y $38.67 \mathrm{mg} \cdot \mathrm{L}^{-1} \cdot \mathrm{d}^{-1}$ en MDP y 24.87 y $26.41 \mathrm{mg} \cdot \mathrm{L}^{-1} \cdot \mathrm{d}^{-1}$ en $\mathrm{AR}$, cantidades significativamente superiores a las productividades lipídicas en MB, MBCA y MPA

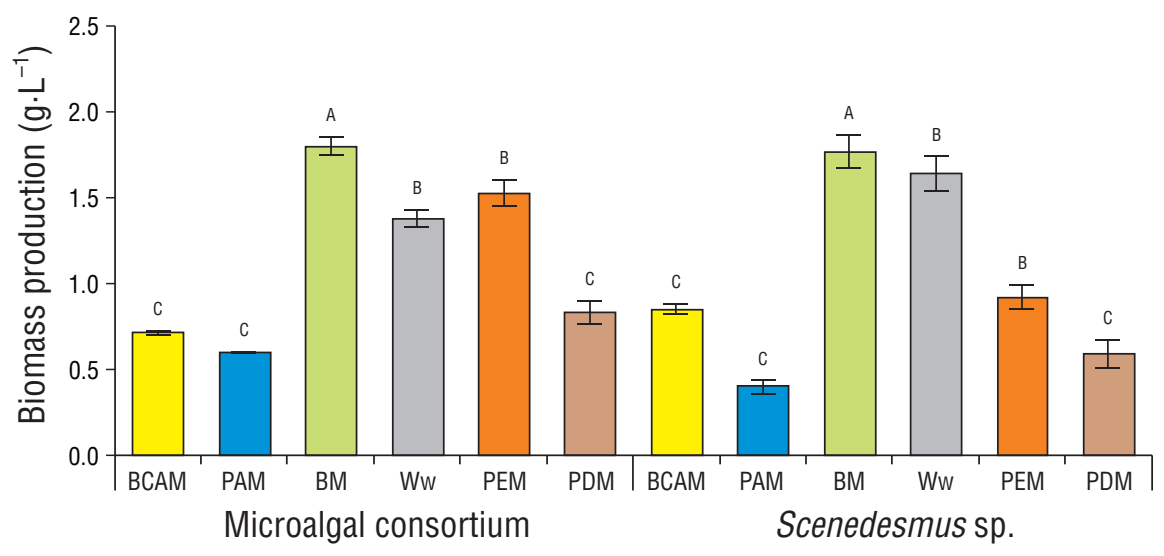

Figure 1. Biomass production with the microalgal consortium and Scenedesmus sp. cultured in different media. BCAM, secondary treated wastewater added with $0.1977 \mathrm{~g} \cdot \mathrm{L}^{-1} \mathrm{NH}_{4} \mathrm{HCO}_{3}$; PAM, secondary treated wastewater enriched with $0.3303 \mathrm{~g} \cdot \mathrm{L}^{-1}\left(\mathrm{NH}_{4}\right)_{2} \mathrm{HPO}$; $\mathrm{BM}, \mathrm{Bayfolan}$ medium; Ww, wastewater; PEM, tap water with $23.5 \%$ of piggery wastewater; PDM, tap water with $39.75 \%$ of piggery wastewater digestate.

Figura 1. Producción de biomasa con el consorcio de microalgas y Scenedesmus sp. cultivadas en diferentes medios. BCAM, aguas residuales

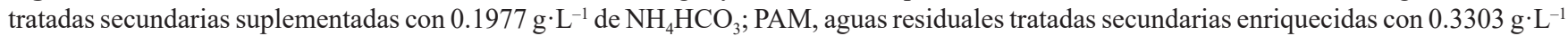
de $\left(\mathrm{NH}_{4}\right)_{2} \mathrm{HPO}_{4}$; BM, medio Bayfolan; Ww, aguas residuales sin tratar; PEM, agua del grifo con 23.5\% de aguas residuales porcinas; PDM, agua del grifo con $39.75 \%$ de digestatos de aguas residuales porcinas. 


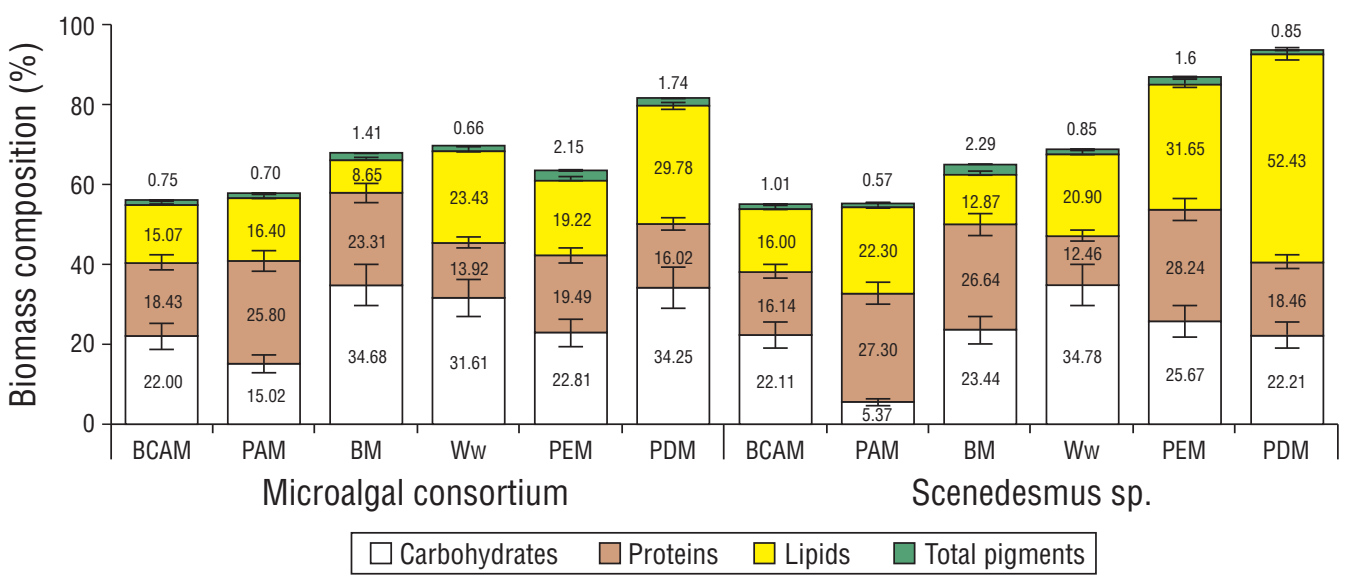

Figure 2. Biochemical composition of the biomass (percent yield) of the microalgal consortium and Scenedesmus sp. cultured in different media. BCAM, secondary treated wastewater added with $0.1977 \mathrm{~g} \cdot \mathrm{L}^{-1} \mathrm{NH}_{4} \mathrm{HCO}_{3}$; PAM, secondary treated wastewater enriched with $0.3303 \mathrm{~g} \cdot \mathrm{L}^{-1}\left(\mathrm{NH}_{4}\right)_{2} \mathrm{HPO}_{4}$; BM, Bayfolan medium; Ww, raw wastewater; PEM, tap water with $23.5 \%$ of piggery wastewater; PDM, tap water with $39.75 \%$ of piggery wastewater digestate.

Figura 2. Composición bioquímica de la biomasa (porcentaje de rendimiento) del consorcio de microalgas y Scenedesmus sp. cultivadas en diferentes medios. BCAM, aguas residuales tratadas secundarias suplementadas con $0.1977 \mathrm{~g} \cdot \mathrm{L}^{-1}$ de $\mathrm{NH}_{4} \mathrm{HCO}_{3}$; $\mathrm{PAM}$, aguas residuales tratadas secundarias enriquecidas con $0.3303 \mathrm{~g} \cdot \mathrm{L}^{-1}$ de $\left(\mathrm{NH}_{4}\right)_{2} \mathrm{HPO}_{4}$; BM, medio Bayfolan; Ww, aguas residuales sin tratar; PEM, agua del grifo con $23.5 \%$ de aguas residuales porcinas; PDM, agua del grifo con $39.75 \%$ de digestatos de aguas residuales porcinas.

were significantly higher with respect to those obtained with BCAM, PAM, Ww, and PDM (Table 2). The protein productivities obtained with the microalgal consortium and Scenedesmus sp. were, respectively, $32.34 \pm 2.36 \mathrm{mg} \cdot \mathrm{L}^{-1} \cdot \mathrm{d}^{-1}$ and $36.32 \pm 2.10 \mathrm{mg} \cdot \mathrm{L}^{-1} \cdot \mathrm{d}^{-1}$ in $\mathrm{BM}$ and $37.28 \pm 5.33 \mathrm{mg} \cdot \mathrm{L}^{-1} \cdot \mathrm{d}^{-1}$ and $32.68 \pm 5.18 \mathrm{mg} \cdot \mathrm{L}^{-1} \cdot \mathrm{d}^{-1}$ in PEM, and while they were significantly lower in BCAM, PAM, Ww, and PDM, the productivity in PAM was 4 times lower than that obtained in PEM and BM.

The highest productivity of carbohydrates from the microalgal consortium was obtained in BM $(48.13 \pm$ $\left.3.38 \mathrm{mg} \cdot \mathrm{L}^{-1} \cdot \mathrm{d}^{-1}\right)$ and that from Scenedesmus $\mathrm{sp}$. was obtained in Ww $\left(43.95 \pm 3.32 \mathrm{mg} \cdot \mathrm{L}^{-1} \cdot \mathrm{d}^{-1}\right)$, both significantly higher than those in BCAM, PAM, PEM, and PDM (50\% lower than $\mathrm{BM}$ (Table 2). In BM, Ww, and PDM, up to $35 \%$ of carbohydrates were obtained in the biomass (Fig. 2).

Regarding the productivities of total pigments, no significant differences were observed between the microalgal consortium and Scenedesmus sp. in the BM and PEM. On the other hand, in BCAM, PAM, Ww, and PDM, the production of total pigments was up to 18 times lower than in $\mathrm{BM}$ (Table 2).

\section{Nutrient removal}

In $\mathrm{BCAM}, \mathrm{PAM}$, and $\mathrm{Ww}, \mathrm{NH}_{4}^{+}$removal was $60 \%$ and $95 \%$ on the third and sixth day, respectively, whereas in PEM and PDM, $100 \%$ of $\mathrm{NH}_{4}^{+}$had already been removed by day three. In BCAM, $\mathrm{NH}_{4}^{+}, \mathrm{NO}_{3}^{-}$, and $\mathrm{PO}_{4}{ }^{3-}$ removals were higher than $92 \%$. The initial concentration of $\mathrm{PO}_{4}{ }^{3-}$ was $12-14 \mathrm{mg} \cdot \mathrm{L}^{-1}$ with a removal percentage of $92 \%$, whereas in BM, 93\% removal was achieved (Table 4). In
(Tabla 2). En AR, MBCA, MPA, MEP y MDP se eliminó el $90 \%-100 \%$ del $\mathrm{NH}_{4}^{+}$desde el día 3 y, en consecuencia, hubo una limitación de $\mathrm{N}$.

Los perfiles de ácidos grasos para el consorcio de microalgas y Scenedesmus sp. en los diferentes medios consistieron en ácido palmítico (C16:0), ácido palmitoleíco (C16:1), ácido esteárico (C18:0), ácido oleíco (C18:1), ácido linoleíco (C18:2) y ácido linolénico (C18:3) (Tabla 3), que son aptos para la producción de biodiesel (Anand et al. 2018, May-Cua et al. 2019). Los medios de cultivo MPA, MEP y MDP exhibieron una mayor proporción de ácidos grasos saturados (60\%-69\% del total de EMAG) que MBCA, MB y AR (39\%-48\% del total de EMAG).

\section{Efecto del medio sobre la productividad de proteínas, carbohidratos y pigmentos totales}

Las productividades de proteínas obtenidas en los cultivos del consorcio de microalgas y Scenedesmus sp. con MB y MEP fueron significativamente mayores con respecto a aquellas obtenidas con MBCA, MPA, AR y MDP (Tabla 2). Las productividades proteicas obtenidas con el consorcio de microalgas y Scenedesmus sp. fueron, respectivamente, $32.34 \pm 2.36 \mathrm{mg} \cdot \mathrm{L}^{-1} \cdot \mathrm{d}^{-1}$ y $36.32 \pm 2.10 \mathrm{mg} \cdot \mathrm{L}^{-1} \cdot \mathrm{d}^{-1}$ en $\mathrm{MB}$ y $37.28 \pm 5.33 \mathrm{mg} \cdot \mathrm{L}^{-1} \cdot \mathrm{d}^{-1}$ y $32.68 \pm 5.18 \mathrm{mg} \cdot \mathrm{L}^{-1} \cdot \mathrm{d}^{-1}$ en MEP, y mientras que en MBCA, MPA, AR y MDP fueron significativamente menores, la productividad en MPA fue 4 veces menor que la obtenida en MEP y MB.

La mayor productividad de carbohidratos del consorcio de microalgas se obtuvo en MB $\left(48.13 \pm 3.38 \mathrm{mg} \cdot \mathrm{L}^{-1} \cdot \mathrm{d}^{-1}\right)$ y la de Scenedesmus sp. se obtuvo en AR (43.95 $\left.\pm 3.32 \mathrm{mg} \cdot \mathrm{L}^{-1} \cdot \mathrm{d}^{-1}\right)$, ambas significativamente más altas que las encontradas en 
BCAM, $\mathrm{NO}_{3}^{-}$removal was $99 \%$, whereas in PAM it was only $59 \%$ with the microalgal consortium and null with Scenedesmus sp. In BM, $\mathrm{NH}_{4}{ }^{+}$and $\mathrm{PO}_{4}{ }^{3-}$ removals were $90 \%$ and $93 \%-94 \%$ with the microalgal consortium and Scenedesmus sp., respectively, whereas the removal of $\mathrm{NO}_{3}{ }^{-}$with Scenedesmus sp. was 30\% lower than that obtained with the consortium (Table 4). Regarding COD, in PEM, 1,043 $\mathrm{mg} \cdot \mathrm{L}^{-1}$ of COD were removed with Scenedesmus sp. (86\%), whereas in PDM only $26 \mathrm{mg} \cdot \mathrm{L}^{-1}$ of COD (10\%) were removed.

\section{$\mathrm{NH}_{4}{ }^{+}$losses by stripping}

The highest loss of $\mathrm{NH}_{4}{ }^{+}$by volatilization $\left(\right.$as $\mathrm{NH}_{3}$ ) was recorded in PDM, that is, $33 \%\left(8.70 \pm 1.78 \mathrm{mg} \cdot \mathrm{L}^{-1} \cdot \mathrm{d}^{-1} \mathrm{NH}_{4}^{+}\right)$ for the consortium and $46 \%\left(11.53 \pm 0.32 \mathrm{mg} \cdot \mathrm{L}^{-1} \cdot \mathrm{d}^{-1} \mathrm{NH}_{4}^{+}\right)$ for Scenedesmus sp. at $\mathrm{pH}$ of 9.93 and 10.03, respectively, with no significant difference between them. In PEM the loss was significantly lower than in PDM, with 2\% (2.24 \pm $\left.0.58 \mathrm{mg} \cdot \mathrm{L}^{-1} \cdot \mathrm{d}^{-1} \mathrm{NH}_{4}^{+}\right)$for the consortium and $7 \%(0.56 \pm$ $0.42 \mathrm{mg} \cdot \mathrm{L}^{-1} \cdot \mathrm{d}^{-1} \mathrm{NH}_{4}{ }^{+}$) for Scenedesmus sp. at an average $\mathrm{pH}$ of 9.68 .

\section{Discussion}

Biomass production in $\mathrm{Ww}$ was $15.33 \%$ lower with the microalgal consortium compared with that obtained with Scenedesmus sp., whereas in PEM, biomass production with Scenedesmus sp. was $40 \%$ lower than that obtained with the microalgal consortium. Lam et al. (2017) cultured C. vulgaris in non-sterilized wastewater $\left(2.70\right.$ and $24.19 \mathrm{mg} \cdot \mathrm{L}^{-1}$ of total $\mathrm{N}$ and $\mathrm{P}$, respectively), obtaining $40.76 \mathrm{mg} \cdot \mathrm{L}^{-1} \cdot \mathrm{d}^{-1}$ (dry weight) of biomass; this productivity was 3 times lower than that obtained in $\mathrm{Ww}$ in the present study (initial concentration of 32.20 and $8.84 \mathrm{mg} \cdot \mathrm{L}^{-1}$ of total $\mathrm{N}$ and $\mathrm{P}$, respectively). Unlike in the other 5 media, in BM, which was formulated with the commercial fertilizer Bayfolan, the main source of $\mathrm{N}$ was $\mathrm{NO}_{3}^{-}$; moreover, $\mathrm{P}$ contents varied significantly between media (Table 4). Since the main goal of the present work was to identify a nonconventional medium that could be used at large scale, the $\mathrm{C} / \mathrm{P}$ and $\mathrm{COD} / \mathrm{N} / \mathrm{P}$ ratios were not adjusted. However, particular care was given to $\mathrm{N}$ concentrations during the preparation of the media. The results obtained from the experimentation with all the media showed that the 2 best options to produce biomass were $\mathrm{Ww}$ and PEM, both of which involve residue treatment and are available at low cost.

Nayak et al. (2016) reported the growth of Scenedesmus sp. in a 500-mL Erlenmeyer flask with $200 \mathrm{~mL}$ of medium, prepared with $1 \mathrm{~g} \cdot \mathrm{L}^{-1}$ of a NPK fertilizer (10:26:26) and $0.10 \mathrm{~g} \cdot \mathrm{L}^{-1}$ of urea, obtaining a biomass productivity of $45 \mathrm{mg} \cdot \mathrm{L}^{-1} \cdot \mathrm{d}^{-1}$ (peso seco). A 2 -fold biomass production and 2.8 times higher productivity were obtained in the present study with Scenedesmus sp. and the consortium in BM. The Bayfolan fertilizer (N:P:K, 11:1:1) is a foliar fertilizer that contains micronutrients, vitamins, and indoleacetic acid
MBCA, MPA, MEP y MDP (50\% más bajas que en MB) (Tabla 2). En MB, AR y MDP se obtuvo hasta un 35\% de carbohidratos en la biomasa (Fig. 2).

Con respecto a las productividades de los pigmentos totales, no hubo diferencias significativas entre el consorcio de microalgas y Scenedesmus sp. en MB y MEP. Por otro lado, en MBCA, MPA, AR y MDP, la producción de pigmentos totales fue hasta 18 veces menor que en MB (Tabla 2).

\section{Eliminación de nutrientes}

En MBCA, MPA y AR, la remoción de $\mathrm{NH}_{4}^{+}$fue del $60 \%$ y $95 \%$ al tercer y sexto día, respectivamente, mientras que en MEP y MDP, al tercer día, ya se había eliminado el $100 \%$ de $\mathrm{NH}_{4}^{+}$. En MBCA, las remociones de $\mathrm{NH}_{4}^{+}, \mathrm{NO}_{3}{ }^{-}$ y $\mathrm{PO}_{4}{ }^{3-}$ fueron superiores al $92 \%$. La concentración inicial de $\mathrm{PO}_{4}{ }^{3-}$ fue de $12-14 \mathrm{mg} \cdot \mathrm{L}^{-1}$, con un porcentaje de remoción del 92\%, mientras que en $\mathrm{BM}$ se logró una remoción del 93\% (Tabla 4). En MBCA, la remoción de $\mathrm{NO}_{3}{ }^{-}$fue del $99 \%$, mientras que en MPA fue solo del $59 \%$ con el consorcio de microalgas y nulo con Scenedesmus sp. En MB, la remoción de $\mathrm{NH}_{4}{ }^{+}$y $\mathrm{PO}_{4}{ }^{3-}$ fue del $90 \%$ y $93 \%-94 \%$ con el consorcio de microalgas y Scenedesmus sp., respectivamente, mientras que la remoción de $\mathrm{NO}_{3}{ }^{-}$con Scenedesmus sp. fue $30 \%$ menor que la obtenida con el consorcio (Tabla 4). En cuanto a la DQO, en MEP, se eliminaron $1,043 \mathrm{mg} \cdot \mathrm{L}^{-1}$ de DQO con Scenedesmus sp. (86\%), mientras que en MDP solo se eliminaron $26 \mathrm{mg} \cdot \mathrm{L}^{-1}$ de DQO (10\%).

\section{Pérdidas de $\mathrm{NH}_{4}^{+}$por stripping}

La mayor pérdida de $\mathrm{NH}_{4}{ }^{+}$por volatilización $\left(\right.$como $\mathrm{NH}_{3}$ ) se registró en MDP, es decir, $33 \%\left(8.70 \pm 1.78 \mathrm{mg} \cdot \mathrm{L}^{-1} \cdot \mathrm{d}^{-1} \mathrm{de}\right.$ $\left.\mathrm{NH}_{4}^{+}\right)$para el consorcio y $46 \%\left(11.53 \pm 0.32 \mathrm{mg} \cdot \mathrm{L}^{-1} \cdot \mathrm{d}^{-1} \mathrm{de}\right.$ $\mathrm{NH}_{4}^{+}$) para Scenedesmus sp., a $\mathrm{pH}$ de 9.93 y 10.03 , respectivamente; no hubo diferencia significativa entre estos dos. En MEP la pérdida fue significativamente menor que en MDP, con $2 \%\left(2.24 \pm 0.58 \mathrm{mg} \cdot \mathrm{L}^{-1} \cdot \mathrm{d}^{-1} \mathrm{de} \mathrm{NH}_{4}^{+}\right)$para el consorcio y $7 \%\left(0.56 \pm 0.42 \mathrm{mg} \cdot \mathrm{L}^{-1} \cdot \mathrm{d}^{-1}\right.$ de $\left.\mathrm{NH}_{4}^{+}\right)$para Scenedesmus sp. a un $\mathrm{pH}$ promedio de 9.68 .

\section{Discusión}

La producción de biomasa con el consorcio de microalgas en AR fue $15.33 \%$ menor con el consorcio de microalgas en comparación con la obtenida con Scenedesmus sp., mientras que en MEP, la producción de biomasa con Scenedesmus sp. fue $40 \%$ menor que la obtenida con el consorcio de microalgas. Lam et al. (2017) cultivaron C. vulgaris en aguas residuales no esterilizadas $\left(2.70\right.$ y $24.19 \mathrm{mg} \cdot \mathrm{L}^{-1}$ de $\mathrm{N}$ total y $\mathrm{P}$, respectivamente) y obtuvieron $40.76 \mathrm{mg} \cdot \mathrm{L}^{-1} \cdot \mathrm{d}^{-1}$ (peso seco) de biomasa; esta productividad fue 3 veces menor que la obtenida en AR en el presente estudio (concentración inicial de 32.20 y $8.84 \mathrm{mg} \cdot \mathrm{L}^{-1}$ de $\mathrm{N}$ total y $\mathrm{P}$, respectivamente). A diferencia de los otros 5 medios, en MB, que fue formulado 


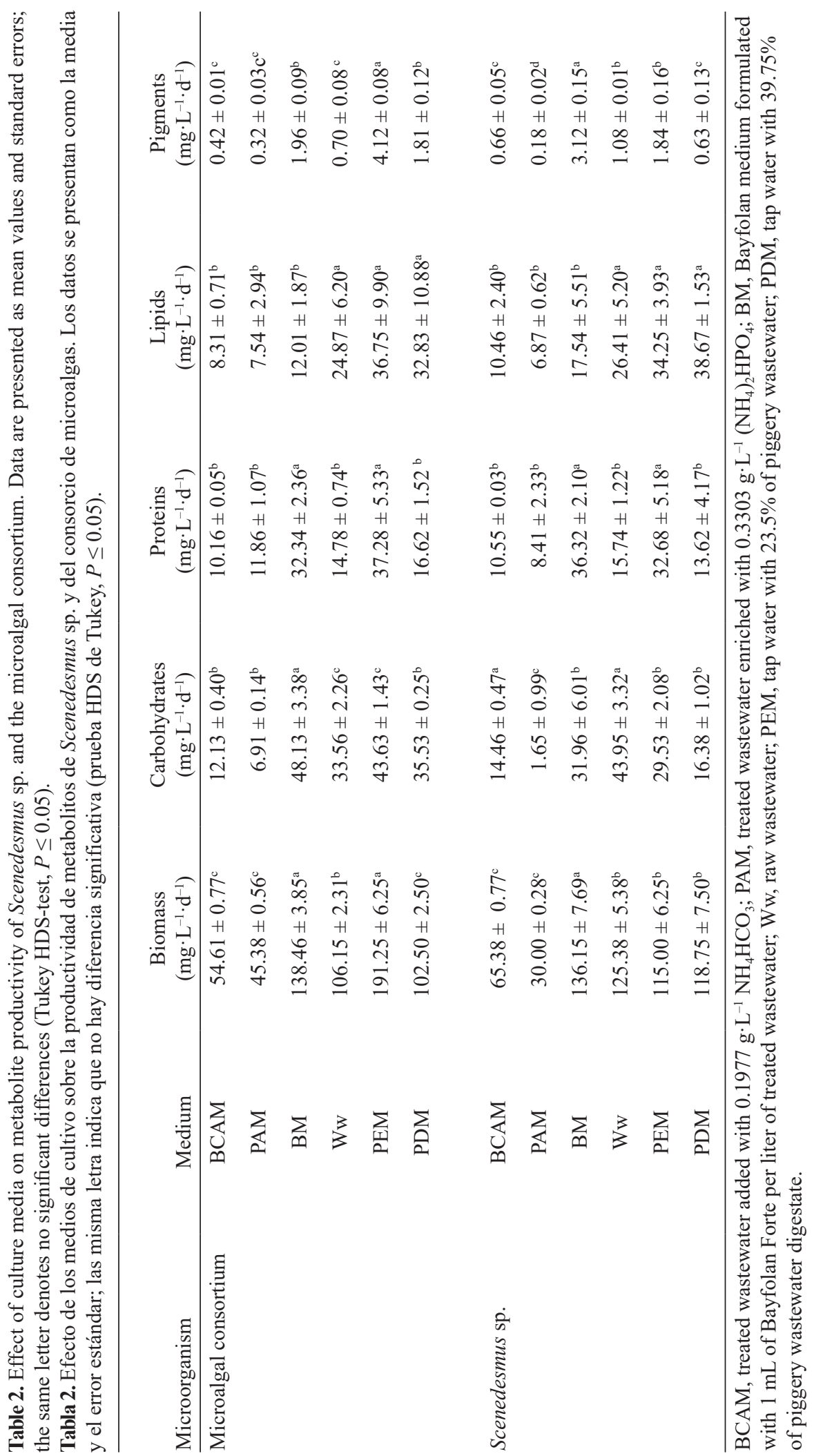


Ciencias Marinas, Vol. 47, No. 2, 2021

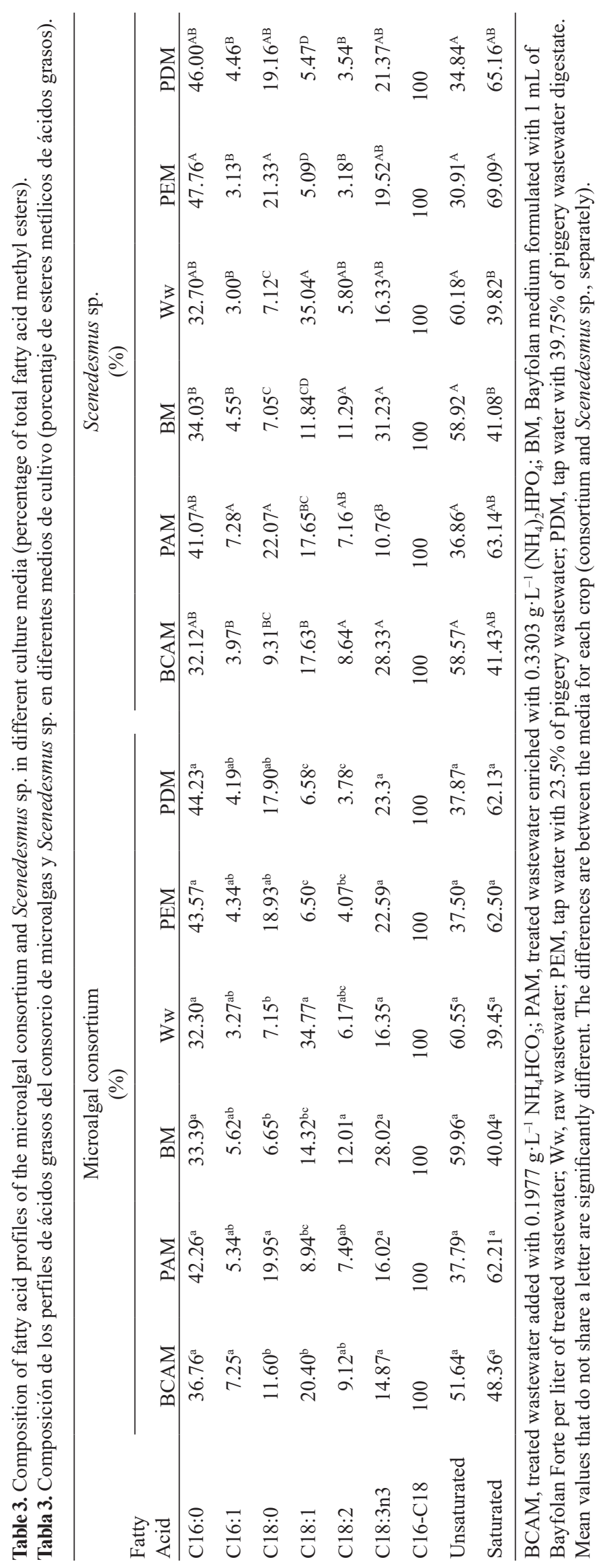




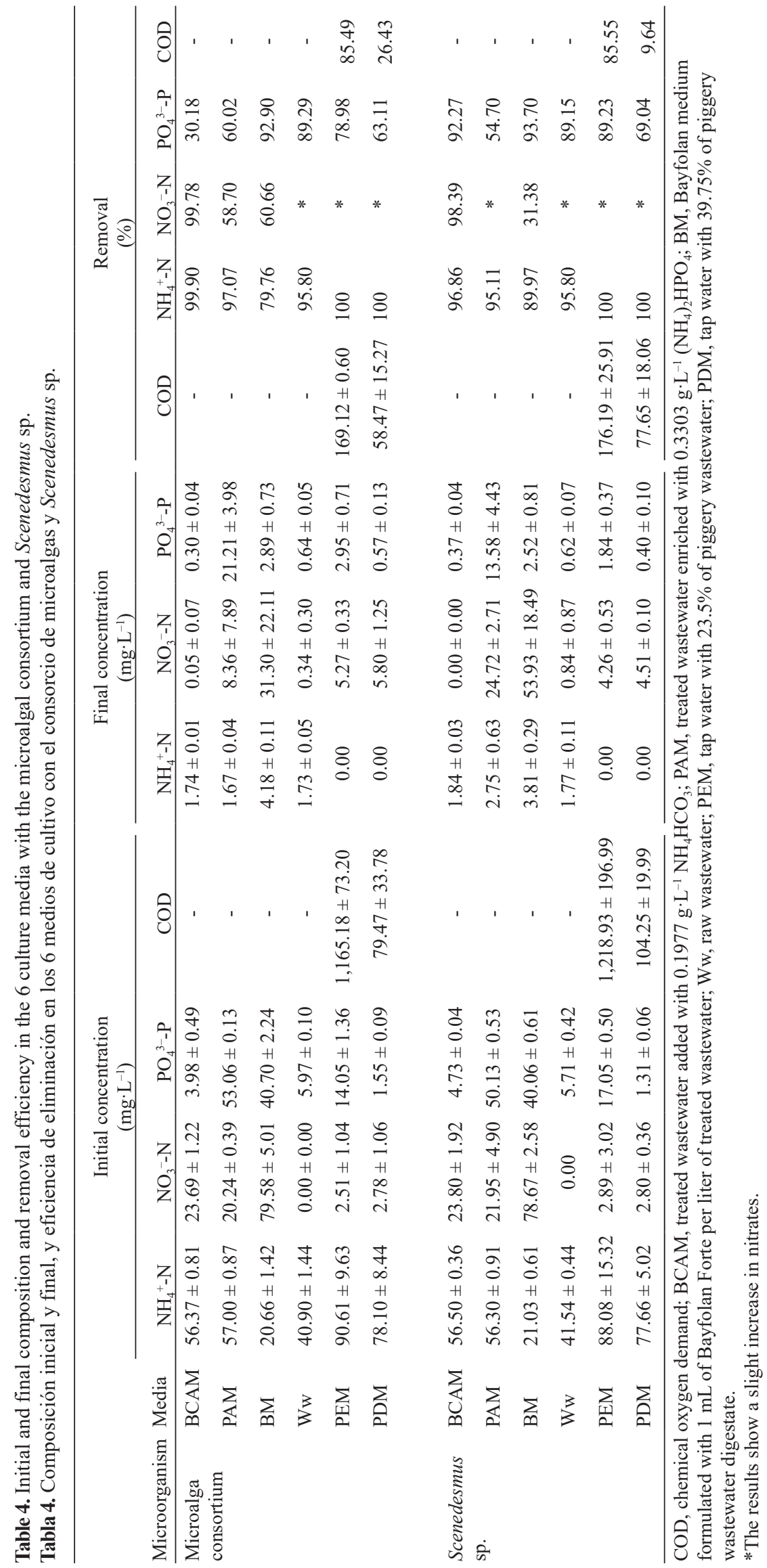


(phytohormone). This auxin regulates growth in higher plants, and in several species of microalgae, it increases growth rate, stress tolerance, lipid content, and biomass productivity ( $\mathrm{Lu}$ and $\mathrm{Xu}$ 2015). Muriellopsis sp. and Pseudokirchneriella subcapitata grown in $300-\mathrm{mL}$ bubble-column glass bioreactors containing freshwater with $40 \%-50 \%$ concentrate from a wastewater treatment plant, under controlled conditions (temperature of $25^{\circ} \mathrm{C}$, aeration of $0.2 \mathrm{vvm}, \mathrm{CO}_{2}$ injected on demand, artificial illumination under a 12:12 h light:dark cycle, $1,850 \mu \mathrm{E} \cdot \mathrm{m}^{-2} \cdot \mathrm{s}^{-1}$ ), reached biomass productivity values up to 1.13 and $1.02 \mathrm{~g} \cdot \mathrm{L}^{-1} \cdot \mathrm{d}^{-1}$, respectively (Morales-Amaral et al. 2015). Moreover, Gomez et al. (2013) cultured Muriellopsis sp. in the same bubble-column, using TWW as medium and controlled conditions (temperature of $23 \pm 2{ }^{\circ} \mathrm{C}, 8.0 \pm$ $0.1 \mathrm{pH}$, on-demand $\mathrm{CO}_{2}$ injection into the airflow entering the reactors, and artificial illumination 12:12 h light:dark cycle, $800 \mu \mathrm{E} \cdot \mathrm{m}^{-2} \cdot \mathrm{s}^{-1}$ ), and the maximum biomass productivity they obtained was $0.5 \mathrm{~g} \cdot \mathrm{L}^{-1} \cdot \mathrm{d}^{-1}$. In the 2 latter reports, productivities were much higher than those obtained in the present study.

Chlorella vulgaris tolerates high $\mathrm{NH}_{4}{ }^{+}$concentrations. However, when $\mathrm{NH}_{4}{ }^{+}$exceeds $110-130 \mathrm{mg} \cdot \mathrm{L}^{-1}$, cell growth inhibition occurs (Sanz-Luque et al. 2015). The inhibition of microalgal growth caused by $\mathrm{NH}_{4}{ }^{+}$becomes severe when the $\mathrm{NH}_{4}{ }^{+}$content reaches $1,030.36 \mathrm{mg} \cdot \mathrm{L}^{-1}$ (Park et al. 2010). In the present study, the $\mathrm{NH}_{4}^{+}$concentration in the medium was below $90.61 \mathrm{mg} \cdot \mathrm{L}^{-1}$ (Table 4).

Lipid concentrations in cells increase when the source of nitrogen is limited (Eroglu et al. 2015, May Cua et al. 2019). $\mathrm{N}$ is a critical factor for regulating algal cell lipid content; lipid accumulation increases when nitrogen becomes the growth limiting factor (Chen et al. 2011). However, N limitation minimizes algal growth; the 2 conditions of high lipid content and high algal productivity are mutually exclusive.

Nam et al. (2017) cultivated C. vulgaris in residual water of pig excreta with a total $\mathrm{N}$ concentration of $307.2 \mathrm{mg} \cdot \mathrm{L}^{-1}$ for $16 \mathrm{~d}$, obtaining a biomass and lipid concentration of 3.96 and $1.072 \mathrm{~g} \cdot \mathrm{L}^{-1}$, respectively. In the present work, the production of biomass and lipids was approximately $61 \%$ and $72 \%$ lower in PEM, respectively, with total $\mathrm{N}$ concentration being $\sim 5$ times lower (Fig. 1). In the case of $\mathrm{Ww}$, the concentration of biomass and lipids was of 58\% and 68\% lower, respectively, and the total $\mathrm{N}$ concentration was 9 times lower. Regarding BM, the production of biomass and lipids was $54 \%$ and $85 \%$ lower, respectively, having the same total $\mathrm{N}$ concentration as PEM.

The loss of $\mathrm{NH}_{4}{ }^{+}$can be caused by several factors, such as assimilation by microalgae, denitrification processes by bacteria, and $\mathrm{NH}_{4}^{+}$stripping at high $\mathrm{pH}$ levels in the medium. In the case of $\mathrm{P}$, the removal is due to assimilation by microalgae and precipitation in the form of calcium phosphate at $\mathrm{pH}$ levels close to 9 (Walker 2015). In this study, the initial $\mathrm{pH}$ of $\mathrm{Ww}$ and $\mathrm{BM}$ was 8.5 and it increased during the growth of the consortium and Scenedesmus sp., reaching a value of 11.5 . con el fertilizante comercial Bayfolan, la principal fuente de $\mathrm{N}$ fue el $\mathrm{NO}_{3}^{-}$; además, el contenido de $\mathrm{P}$ varió significativamente entre los medios (Tabla 4). Dado que el objetivo principal del presente trabajo era identificar un medio no convencional que pudiera utilizarse a gran escala, no se ajustaron las relaciones $\mathrm{C} / \mathrm{P}$ y DQO/N/P. Sin embargo, se prestó especial atención a la concentración de $\mathrm{N}$ durante la preparación de los medios. Los resultados obtenidos de la experimentación con todos los medios mostraron que las 2 mejores opciones para producir biomasa fueron AR y MEP, que involucran el tratamiento de residuos y están disponibles a bajo costo.

Nayak et al. (2016) reportaron el crecimiento de Scenedesmus sp. en matraz Erlenmeyer de $500 \mathrm{~mL}$ con $200 \mathrm{~mL}$ de medio, preparado con $1 \mathrm{~g} \cdot \mathrm{L}^{-1}$ de fertilizante NPK (10:26:26) y $0.10 \mathrm{~g} \cdot \mathrm{L}^{-1}$ de urea, y la productividad de biomasa fue de $45 \mathrm{mg} \cdot \mathrm{L}^{-1} \cdot \mathrm{d}^{-1}$ (peso seco). En el presente estudio se obtuvo una producción de biomasa 2.0 veces mayor y una productividad 2.8 veces mayor con Scenedesmus sp. y el consorcio en medio MB. El fertilizante Bayfolan (N:P:K, 11:1:1) es un fertilizante foliar que contiene micronutrientes, vitaminas y ácido indolacético (fitohormona). Esta auxina regula el crecimiento en plantas superiores y aumenta la tasa de crecimiento, la tolerancia al estrés, el contenido de lípidos y la productividad de la biomasa en varias especies de microalgas (Lu y Xu 2015). Muriellopsis sp. y Pseudokirchneriella subcapitata cultivadas en agua dulce con $40 \%-50 \%$ de un concentrado de una planta de tratamiento de aguas residuales en biorreactores de vidrio de columna de burbujas de $300 \mathrm{~mL}$, bajo condiciones controladas (temperatura de $25{ }^{\circ} \mathrm{C}$, aireación de $0.2 \mathrm{vvm}$, inyección de $\mathrm{CO}_{2}$ a demanda, iluminación artificial bajo ciclo de 12:12 h luz:oscuridad, $1,850 \mu \mathrm{E} \cdot \mathrm{m}^{-2} \cdot \mathrm{s}^{-1}$ ), alcanzaron valores de productividad de biomasa de hasta 1.13 y $1.02 \mathrm{~g} \cdot \mathrm{L}^{-1} \cdot \mathrm{d}^{-1}$, respectivamente (Morales-Amaral et al. 2015). Además, Gomez et al. (2013) cultivaron Muriellopsis sp. en la misma columna de burbujeo utilizando como medio ART, bajo condiciones controladas (temperatura de $23 \pm 2{ }^{\circ} \mathrm{C}, \mathrm{pH}$ de $8.0 \pm 0.1$, inyección de $\mathrm{CO}_{2}$ en el flujo de aire que ingresa a los reactores a demanda, iluminación artificial bajo ciclo de 12:12 h luz:oscuridad, $800 \mu \mathrm{E} \cdot \mathrm{m}^{-2} \cdot \mathrm{s}^{-1}$ ), y la productividad máxima de biomasa que obtuvieron fue de $0.5 \mathrm{~g} \cdot \mathrm{L}^{-1} \cdot \mathrm{d}^{-1}$. En estos 2 últimos informes, las productividades fueron muy superiores a las obtenidas en el presente trabajo.

Chlorella vulgaris tolera altas concentraciones de $\mathrm{NH}_{4}{ }^{+}$. Sin embargo, por encima de $110-130 \mathrm{mg} \cdot \mathrm{L}^{-1}$ de $\mathrm{NH}_{4}{ }^{+}$hay una inhibición del crecimiento celular (Sanz-Luque et al. 2015). La inhibición del crecimiento de microalgas causada por $\mathrm{NH}_{4}{ }^{+}$se vuelve severa cuando el contenido de $\mathrm{NH}_{4}{ }^{+}$ alcanza $1,030.36 \mathrm{mg} \cdot \mathrm{L}^{-1}$ (Park et al. 2010). En el presente trabajo, la concentración de $\mathrm{NH}_{4}{ }^{+}$en el medio estuvo por debajo de $90.61 \mathrm{mg} \cdot \mathrm{L}^{-1}$ (Tabla 4).

La concentración de lípidos en las células aumenta cuando existe una limitación de la fuente de N (Eroglu et al. 2015, May-Cua et al. 2019). El N es un factor crítico para regular el 
The preference for the type of $\mathrm{N}$ source varies from one strain of microalgae to another. $\mathrm{NH}_{4}{ }^{+}$is the most easily assimilated $\mathrm{N}$ source, followed by $\mathrm{NO}_{3}{ }^{-}$and $\mathrm{NO}_{2}{ }^{-}$. $\mathrm{NH}_{4}{ }^{+}$is directly assimilated by the cell, whereas $\mathrm{NO}_{2}^{-}$and $\mathrm{NO}_{3}^{-}$are transported to the inner part of the cell and reduced to $\mathrm{NH}_{4}{ }^{+}$by nitrite and nitrate reductases (Liao et al. 2018). In Ww, PEM, and PDM the concentration of $\mathrm{NO}_{3}{ }^{-}$was up to twice the initial one (Table 4). The processes of $\mathrm{N}$ removal in wastewater and activated sludge, the nitrification of $\mathrm{NH}_{4}{ }^{+}$, which is oxidized to $\mathrm{NO}_{3}^{-}$, and the denitrification of $\mathrm{NO}_{3}{ }^{-}$, which is reduced to $\mathrm{N}_{2}$, have been widely studied (Larsdotter 2006). These processes involve nitrifying and denitrifying bacteria: the former are autotrophic, do not need organic carbon, and consume large amounts of oxygen; the latter are anaerobic heterotrophs or aerobic autotrophs and require a source of carbon. The first step in the nitrification process is the oxidation of $\mathrm{NH}_{4}{ }^{+}$to $\mathrm{NO}_{2}^{-}$by bacteria belonging to the genus Nitrosomonas. In the second step, the oxidation of $\mathrm{NO}_{2}^{-}$to $\mathrm{NO}_{3}{ }^{-}$occurs by bacteria belonging to the genus Nitrobacter. In denitrification, bacteria reduce $\mathrm{NO}_{3}{ }^{-}$or $\mathrm{NO}_{2}{ }^{-}$to $\mathrm{N}_{2}$ gas (Jia and Yuan 2016). In mixed cultures of microalgae and bacteria in wastewater, microalgae can produce organic compounds that bacteria can assimilate; on the other hand, some bacteria produce hormones that promote microalgal growth (Liu et al. 2017). Approximately $60 \%$ of $\mathrm{NH}_{4}^{+}$is oxidized by nitrifying bacteria, while microalgae assimilate $40 \%$ (Vargas et al. 2016).

High $\mathrm{pH}$ levels can promote $\mathrm{NH}_{3}$ volatilization (removal of NH4-N) and $\mathrm{P}$ removal through $\mathrm{PO}_{4}{ }^{3-}$ precipitation with ferric iron, calcium, and magnesium (Park et al. 2011). In PDM, a medium in which greater ammonium loss due to volatilization was observed, $\mathrm{pH}$ values were more basic than in PEM; in addition, PEM contained a higher quantity of organic matter that could have minimized $\mathrm{NH}_{3}$ losses. For example, Wu et al. (2017) reported losses of $5 \%$ of $\mathrm{NH}_{4}{ }^{+}$by stripping during $4 \mathrm{~d}$ in wastewater without microalgae (initial concentration of $30.26 \mathrm{mg} \cdot \mathrm{L}^{-1} \mathrm{NH}_{4}^{+}$).

The present study demonstrated that the cultivation of the microalgal consortium and Scenedesmus sp. with piggery wastewater as the medium is suitable to produce biodiesel given the productivity of biomass and lipids and the high content of saturated fatty acids that were obtained. These productivities were reached due to the nutrient supply attributed to piggery wastewater, which in addition is readily available. Furthermore, cultivation with PEM showed efficient nutrient removal within the first $3 \mathrm{~d}$. As a whole, the results of the present study provide insight on low-cost alternatives to culture microalgae, coupled with valorization of waste as an approach to the eventual production of biodiesel.

\section{ACKNOWLedgments}

This study was supported by the Instituto Politécnico Nacional (SIP 20180825 and SIP 20195715-20195732) and contenido de lípidos de las células de las algas; el aumento de la acumulación de lípidos se produce cuando $\mathrm{N}$ se convierte en el factor limitante del crecimiento (Chen et al. 2011). Sin embargo, la limitación de $\mathrm{N}$ minimiza el crecimiento de algas; las 2 condiciones de alto contenido de lípidos y alta productividad de algas son mutuamente excluyentes.

Nam et al. (2017) cultivaron C. vulgaris en agua residual de excretas porcinas con una concentración de $\mathrm{N}$ total de $307.2 \mathrm{mg} \cdot \mathrm{L}^{-1}$ durante $16 \mathrm{~d}$ y obtuvieron concentraciones de biomasa y lípidos de 3.96 y $1.072 \mathrm{~g} \cdot \mathrm{L}^{-1}$, respectivamente. En el presente trabajo, la producción de biomasa y lípidos fue aproximadamente $61 \%$ y $72 \%$ menor en MEP, respectivamente, con una concentración de $\mathrm{N}$ total $\sim 5$ veces menor (Fig. 1). En el caso de AR la concentración de biomasa y lípidos fue de $58 \%$ y $68 \%$ menor, respectivamente, y la concentración de $\mathrm{N}$ total fue 9 veces menor. Con respecto a $\mathrm{MB}$, la producción de biomasa y lípidos fue $54 \%$ y $85 \%$ menor, respectivamente, con la misma concentración de $\mathrm{N}$ total que en MEP.

La pérdida de $\mathrm{NH}_{4}{ }^{+}$puede deberse a varios factores, como asimilación por microalgas, procesos de desnitrificación por bacterias y stripping de $\mathrm{NH}_{4}{ }^{+}$a $\mathrm{pH}$ elevado del medio. En el caso del P, la eliminación se debe a la asimilación por microalgas y la precipitación en forma de fosfato cálcico a $\mathrm{pH}$ cercano a 9 (Walker 2015). En este estudio, el pH inicial de AR y MB fue de 8.5 y aumentó durante el crecimiento del consorcio y Scenedesmus sp. hasta alcanzar un valor de 11.5.

La preferencia por el tipo de fuente de $\mathrm{N}$ varía de una cepa de microalgas a otra. $\mathrm{El} \mathrm{NH}_{4}{ }^{+}$es la fuente de $\mathrm{N}$ de más fácil asimilación, seguida de $\mathrm{NO}_{3}^{-}$y $\mathrm{NO}_{2}^{-}$. $\mathrm{El} \mathrm{NH}_{4}{ }^{+}$es asimilado directamente por la célula, mientras que el $\mathrm{NO}_{2}^{-}$y el $\mathrm{NO}_{3}^{-}$ se transportan al interior de la célula y se reducen a $\mathrm{NH}_{4}{ }^{+}$ mediante la nitrito y nitrato reductasa (Liao et al. 2018). En AR, MEP y MDP, la concentración de $\mathrm{NO}_{3}^{-}$fue hasta el doble de la inicial (Tabla 4). Los procesos de remoción de $\mathrm{N}$ en aguas residuales y lodos activados, la nitrificación de $\mathrm{NH}_{4}{ }^{+}$, que se oxida a $\mathrm{NO}_{3}^{-}$, y la desnitrificación de $\mathrm{NO}_{3}^{-}$, que se reduce a $\mathrm{N}_{2}$, han sido ampliamente estudiados (Larsdotter 2006). Estos procesos involucran bacterias nitrificantes y desnitrificantes: las primeras son autótrofas, no necesitan carbono orgánico y consumen grandes cantidades de oxígeno; las segundas son heterótrofos anaeróbicos o autótrofos aeróbicos y requieren una fuente de carbono. El primer paso en el proceso de nitrificación es la oxidación del $\mathrm{NH}_{4}{ }^{+}$ a $\mathrm{NO}_{2}{ }^{-}$por bacterias pertenecientes al género Nitrosomonas. En el segundo paso, la oxidación de $\mathrm{NO}_{2}^{-}$a $\mathrm{NO}_{3}{ }^{-}$ocurre por bacterias pertenecientes al género Nitrobacter. En la desnitrificación, las bacterias reducen el $\mathrm{NO}_{3}^{-}$o el $\mathrm{NO}_{2}^{-}$a gas $\mathrm{N}_{2}$ (Jia y Yuan 2016). En cultivos mixtos de microalgas y bacterias en aguas residuales, las microalgas pueden producir compuestos orgánicos que las bacterias pueden asimilar; por otro lado, algunas bacterias producen hormonas que promueven el crecimiento de microalgas (Liu et al. 2017). Aproximadamente el $60 \%$ del $\mathrm{NH}_{4}^{+}$es oxidado por bacterias 
Consejo Nacional de Ciencia y Tecnología (Mexico; grant No. 247402).

\section{REFERENCES}

Acién FG, Fernández JM, Magán JJ, Molina E. 2012. Production cost of a real microalgae production plant and strategies to reduce it. Biotechnol Adv. 30(6):1344-1353. https://doi.org/10.1016/j.biotechadv.2012.02.005

Anand G, Pandey JK, Rana S. 2018. Nanotechnology for Energy and Water: Proceedings of the International Conference NEW2017; 2017; Dehradun (India). Cham (Switzerland): Springer International Publishing AG.

[APHA] American Public Health Association. 1998. Standard Methods for Examination of Water and Wastewater. Washington, DC: APHA. p. 5-16.

[APHA] American Public Health Association. 2005. Standard Methods for the Examination of Water and Wastewater. Washington, DC: APHA.

Boelee NC, Temmink H, Janssen M, Buisman CJN, Wijffels RH. 2011. Nitrogen and phosphorus removal from municipal wastewater effluent using microalgal biofilms. Water Res. 45(18):5925-5933. https://doi.org/10.1016/j.watres.2011.08.044

Chen M, Tang H, Ma H, Holland TC, Ng KYS, Salley SO. 2011. Effect of nutrients on growth and lipid accumulation in the green algae Dunaliella tertiolecta. Bioresour Technol. 102(2):1649-1655. https://doi.org/10.1016/j.biortech.2010.09.062

Chisti Y. 2013. Constraints to commercialization of algal fuels. J Biotechnol. 167(3):201-214. https://doi.org/10.1016/j.jbiotec.2013.07.020

Dickinson KE, Whitney CG, McGinn PJ. 2013. Nutrient remediation rates in municipal wastewater and their effect on biochemical composition of the microalga Scenedesmus sp. AMDD. Algal Res. 2(2):127-134. https://doi.org/10.1016/j.algal.2013.01.009

DuBois M, Gilles KA, Hamilton JK, Rebers PA, Smith F. 1956. Colorimetric method for determination of sugars and related substances. Anal Chem. 28(3):350-356. https://doi.org/10.1021/ac60111a017

El Shimi HI, Moustafa SS. 2017. Biodiesel production from microalgae grown on domestic wastewater: Feasibility and egyptian case study. 82(3):4238-4244. https://doi.org/10.1016/j.rser.2017.05.073

Eroglu E, Smith SM, Raston CL. 2015. Appication of various immobilization techniques for algal bioprocesses. In: Moheimani NR, McHenry MP, de Boer K, Bahri PA (eds.), Biofuel and Biorefinery Technologies 2-Biomass and Biofuels from Microalgae. Switzerland: Springer International Publishing. p. 19-44.

Gómez C, Escudero R, Morales MM, Figueroa FL, FernándezSevilla JM, Acién FG. 2013. Use of secondary-treated wastewater for the production of Muriellopsis sp. Appl Microbiol Biotechnol. 97(5):2239-2249.

https://doi.org/10.1007/s00253-012-4634-7

Gonçalves AL, Pires JCM, Simões M. 2017. A review on the use of microalgal consortia for wastewater treatment. Algal Res. 24(B):403-415. https://doi.org/10.1016/j.algal.2016.11.008

Hernández-García A, Velásquez-Orta SB, Novelo E, YáñezNoguez I, Monje-Ramírez I, Orta-Ledesma MT. 2019. Wastewater-leachate treatment by microalgae: Biomass, carbohydrate and lipid production. Ecotox Environ Safe. $174: 435-444$

https://doi.org/10.1016/j.ecoenv.2019.02.052 nitrificantes, mientras que las microalgas asimilan el $40 \%$ (Vargas et al. 2016).

El pH elevado puede promover la volatilización del $\mathrm{NH}_{3}$ (la eliminación de $\mathrm{NH}_{4}-\mathrm{N}$ ) y la eliminación del $\mathrm{P}$ a través de la precipitación de $\mathrm{PO}_{4}{ }^{3-}$ con hierro férrico, calcio y magnesio no quelados (Park et al. 2011). En MDP, medio en el cual se observó una mayor pérdida de $\mathrm{NH}_{4}{ }^{+}$por volatilización, los valores de $\mathrm{pH}$ fueron más básicos que en MEP; además, MEP contenía una mayor cantidad de materia orgánica que pudo haber minimizado las pérdidas de $\mathrm{NH}_{3}$. Por ejemplo, Wu et al. (2017) reportaron pérdidas del 5\% de $\mathrm{NH}_{4}^{+}$por stripping durante $4 \mathrm{~d}$ en aguas residuales sin microalgas, a una concentración inicial de $30.26 \mathrm{mg} \cdot \mathrm{L}^{-1} \mathrm{de} \mathrm{NH}_{4}{ }^{+}$.

El presente estudio demostró que el cultivo del consorcio de microalgas y Scenedesmus sp. en medio con aguas residuales porcinas es apto para producir biodiesel debido a la productividad de biomasa y lípidos y al alto contenido de ácidos grasos saturados que se obtuvieron. Estas productividades se alcanzaron gracias al aporte de nutrientes atribuido a las aguas residuales porcinas, que además están fácilmente disponibles. Además, el cultivo con MEP presentó una remoción eficiente de nutrientes dentro de los primeros $3 \mathrm{~d}$. Considerando los resultados en conjunto, el presente trabajo proporciona información sobre alternativas de cultivo de microalgas en medios de bajo costo, acoplada a la valorización de residuos como un enfoque para la eventual producción de biodiesel.

\section{Agradecimientos}

Este trabajo fue apoyado por el Instituto Politécnico Nacional (SIP 20180825 y SIP 20195715-20195732) y por el Consejo Nacional de Ciencia y Tecnología (México, subvención No. 247402).

Hillier J, Hawes C, Squire G, Hilton A, Wale S, Smith P. 2009. The carbon footprints of food crop production. Int J Agr Sustain. 7(2):107-118. https://doi.org/10.3763/ijas.2009.0419

Ho S-H, Chen Y-D, Qu W-Y, Liu F-Y, Wang Y. 2019. Algal culture and biofuel production using wastewater. In: Pandey A, Chang JD, Chisti Y (eds.), Biofuels from Algae. 2nd ed. Amsterdam (Netherlands): Elsevier B.V. 603 p. https://doi.org/10.1016/B978-0-444-64192-2.00008-1

Hu B, Zhou W, Min M, Du Z, Chen P, Ma X, Liu Y, Lei H, Shi J, Ruan R. 2013. Development of an effective acidogenically digested swine manure-based algal system for improved wastewater treatment and biofuel and feed production. Appl Ener. 107:255-263. https://doi.org/10.1016/j.apenergy.2013.02.033

Huy M, Kumar G, Kim H-W, Kim S-H. 2018. Photoautotrophic cultivation of mixed microalgae consortia using various organic waste streams towards remediation and resource recovery. Bioresource Technol. 247:576-581. https://doi.org/10.1016/j.biortech.2017.09.108 
Ji M-K, Abou-Shanab RAI, Hwang J-H, Timmes TC. 2013. Removal of nitrogen and phosphorus from piggery wastewater effluent using the green microalga Scenedesmus obliquus. J Environ Eng. 139(9):1198-1205. https://doi.org/10.1061/(asce)ee.1943-7870.0000726

Jia H, Yuan Q. 2016. Removal of nitrogen from wastewater using microalgae and microalgae-bacteria consortia. Cogent Environmental Science. 2(1):1275089. https://doi.org/10.1080/23311843.2016.1275089

Keeney DR, Nelson DW. 1982. Nitrogen-Inorganic Forms. In: Page AL (ed.), Methods of Soil Analysis, Agronomy Monograph 9, Part 2: Chemical and Microbiological Properties. 2nd ed. Madison (WI): American Society of Agronomy. 643-698.

Lam MK, Yusoff MI, Uemura Y, Lim JW, Khoo CG, Lee KT, Ong HC. 2017. Cultivation of Chlorella vulgaris using nutrients source from domestic wastewater for biodiesel production: Growth condition and kinetic studies. Renew Energ. 103:197-207. https://doi.org/10.1016/j.renene.2016.11.032

Larsdotter K. 2006. Wastewater treatment with microalgae-A literature review. Vatten. 62:31-38.

Liao Q, Chang J-S, Herrmann C, Xia A. 2018. Bioreactors for microbial biomass and energy conversion. Singapore: Springer Nature. https://doi.org/10.1007/978-981-10-7677-0

Liu J, Wu Y, Wu C, Muylaert K, Vyverman W, Yu H-Q, Muñoz R, Rittmann B. 2017. Advanced nutrient removal from surface water by a consortium of attached microalgae and bacteria: A review. Bioresource Technol. 241:1127-1137. https://doi.org/10.1016/j.biortech.2017.06.054

Lowry OH, Rosebrough NJ, Farr AL, Randall RJ. 1951. Protein measurement with the folin phenol reagent. J Biol Chem. 193(1):265-275.

Lu Y, Xu J. 2015. Phytohormones in microalgae: a new opportunity for microalgal biotechnology? Trends Plant Sci. 20(5):273-282. https://doi.org/10.1016/j.tplants.2015.01.006

Luo L, He H, Yang C, Wen S, Zeng G, Wu M, Zhou Z, Lou W. 2016. Nutrient removal and lipid production by Coelastrella sp. in anaerobically and aerobically treated swine wastewater. Bioresource Technol. 216:135-141. https://doi.org/10.1016/j.biortech.2016.05.059

May-Cua ER, Toledano-Thompson T, Alzate-Gaviria LM, Barahona-Perez LF. 2019. A cylindrical-conical photobioreactor and a sludge drying bed as an efficient system for cultivation of the green microalgae Coelastrum sp. and dry biomass recovery. Revista Mexicana de Ingeniería Química. 18(1):1-11. ht t ps://doi org/10.24275/u a m/i z t/d c bi/ revmexingquim/2019v18n1/may

Metz B, Meyer L, Bosch P. 2007. Climate Change 2007: Mitigation of Climate Change. New York (NY): Cambridge University Press.

Morales-Amaral MM, Gómez-Serrano C, Acién FG, FernándezSevilla JM, Molina-Grima E. 2015. Production of microalgae using centrate from anaerobic digestion as the nutrient source. Algal Res. 9:297-305. https://doi.org/10.1016/j.algal.2015.03.018

Nam K, Lee H, Hoe S-W, Chang YK, Han JI. 2017. Cultivation of Chlorella vulgaris with swine wastewater and potential for algal biodiesel production. J Appl Phycol. 29(3):1171-1178. https://doi.org/10.1007/s10811-016-0987-0

Nayak M, Thirunavoukkarasu M, Mohanty RC. 2016. Cultivation of freshwater microalga Scenedesmus sp. using a low-cost inorganic fertilizer for enhanced biomass and lipid yield. J Gen Appl Microbiol. 62(1):7-13.

https://doi.org/10.2323/jgam.62.7

Park J, Jin H-F, Lim B-R, Park K-Y, Lee K. 2010. Ammonia removal from anaerobic digestion effluent of livestock waste using green alga Scenedesmus sp. Bioresource Technol. 101(22):86498657. https://doi.org/10.1016/j.biortech.2010.06.142

Park JBK, Craggs RJ, Shilton AN. 2011. Wastewater treatment high rate algal ponds for biofuel production. Bioresource Technol. 102(1):35-42. https://doi.org/10.1016/j.biortech.2010.06.158

Ramírez-López C, Chairez I, Fernandez-Linares L, 2016. A novel culture medium designed for the simultaneous enhancement of biomass and lipid production by Chlorella vulgaris UTEX 26. Bioresour Technol. 212:207-216. https://doi.org/10.1016/j.biortech.2016.04.051

Ritchie RJ. 2006. Consistent sets of spectrophotometric chlorophyll equations for acetone, methanol and ethanol solvents. Photosynth Res. 89(1):27-41.

Rodríguez-Mata AE, Flores-Colunga G, Rangel-Peraza JG, Lizardi-Jiménez MA, Amabilis-Sosa LE. 2019. Estimation of states in photosynthetic systems via chained observers: Design for a tertiary wastewater treatment by using Spirulina maxima on photobioreactor. Revista Mexicana de Ingeniera Quimica. 18(1):273-87.

https://doi.org/10.24275/uam/izt/dcbi/revmexingquim/2019v18n1/ rodriguez

Sanz-Luque E, Chamizo-Ampudia A, Llamas A, Galvan A, Fernandez E. 2015. Understanding nitrate assimilation and its regulation in microalgae. Front Plant Sci. 6:899. https://doi.org/10.3389/fpls.2015.00899

Vargas G, Donoso-Bravo A, Vergara C, Ruiz-Filippi G. 2016. Assessment of microalgae and nitrifiers activity in a consortium in a continuous operation and the effect of oxygen depletion. Electron J Biotechn. 23:63-68. https://doi.org/10.1016/j.ejbt.2016.08.002

Walker HW. 2015. Harmful Algae Blooms in Drinking Water: Removal of Cyanobacterial Cells and Toxins. Boca Raton (FL): CRC Press.

Wang M, Yang Y, Chen Z, Chen Y, Wen Y, Chen B. 2016a. Removal of nutrients from undiluted anaerobically treated piggery wastewater by improved microalgae. Bioresource Technol. 222:130-38.

https://doi.org/10.1016/j.biortech.2016.09.128

Wang Y, Ho S-H, Cheng C-L, Guo W-Q, Nagarajan D, Ren N-Q, Lee D-J, Chang J-S. 2016b. Perspectives on the feasibility of using microalgae for industrial wastewater treatment. Bioresource Technol. 222:485-497. https://doi.org/10.1016/j.biortech.2016.09.106

Wu K-C, Yau Y-H, Ho K-C. 2017. Capability of microalgae for local saline sewage treatment towards biodiesel production. IOP Conf Series. Earth Env Sci. 82:012008. https://doi.org/10.1088/1755-1315/82/1/012008

Xu J, Zhao Y, Zhao G, Zhang H. 2015. Nutrient removal and biogas upgrading by integrating freshwater algae cultivation with piggery anaerobic digestate liquid treatment. Appl Microbiol Biotechnol. 99(15):6493-6501. https://doi.org/10.1007/s00253-015-6537-x

Received 13 April 2020, accepted 25 September 2020. 